\title{
PENGARUH PERSEPSI DAN PENGGUNAAN MEDIA SOSIAL TERHADAP TERPAAN BERITA HOAX TAGAR \#JUSTICEFORAUDREY DI KALANGAN PELAJAR SMA NEGERI DI KECAMATAN PESANGGRAHAN
}

\section{THE EFFECT OF PERCEPTION AND SOCIAL MEDIA USE TOWARD HOAX \#JUSTICEFORAUDREY IN SENIOR HIGH SCHOOL STUDENTS AT PESANGGRAHAN SUBDISTRICT}

\author{
Andy Setyawan ${ }^{1 *}$. \\ ${ }^{1}$ Fakultas Komunikasi dan Bahasa Universitas Bina Sarana Informatika Jl Kayu Jati V No 2, RT. 9/ RW. 5, \\ Rawamangun, Jakarta Timur, 13220. \\ *Korespondensi: philosophyofawan@yahoo.com
}

(Diterima oleh Dewan Redaksi: 01-08-2019)

(Dipublikasikan oleh Dewan Redaksi: 01-10-2019)

\begin{abstract}
This study aims to find out Perception and Social Media Use Toward Hoax \#Justiceforaudrey in Senior High School Students at Pesanggrahan Subdistrict. This study used a qualitative approach and survey method. The sample used was 106 high school students in the Pesanggrahan sub-district, South Jakarta. The results showed that found a significant effect between the perception of hoax news exposure with a regression coefficient of 0.182 greater than 0.05 , and there is a significant influence between the use of social media on the exposure of hoax news with a regression coefficient of 0.537 greater than 0.05. Furthermore, the results obtained by $R$ Square in this study amounted to 0.405 or $40.5 \%$. This means that the influence of the perception and use of social media variables on exposure to hoax news by $40.5 \%$. The remaining $59.5 \%$ is influenced by variables outside this study.
\end{abstract}

Keywords: Perception, Media Social, Hoax

\begin{abstract}
ABSTRAK
Penelitian ini bertujuan untuk melihat persepsi dan penggunaan media sosial terhadap terpaan berita hoax tagar justiceforaudrey dikalangan pelajar. Pendekatan yang digunakan adalah kualitatif, dengan metode survey. Sampel yang digunakan adalah 106 siswa SMA Negeri di kecamatan Pesanggrahan Jakarta Selatan. Dari hasil penelitian didapatkan pengaruh signifikan antara persepsi terhadap terpaan berita hoax dengan koefisien regresi 0,182 lebih besar dr 0,05, dan terdapat pengaruh yang signifikan antara penggunaan media sosial terhadap terpaan berita hoax dengan koefisien regresi 0,537 lebih besar dari 0,05 . Selanjutnya didapatkan hasil R Square dalam penelitian ini sebesar 0.405 atau $40.5 \%$. Hal ini bermakna bahwa pengaruh variabel persepsi dan penggunaan media sosial terhadap terpaan berita hoax sebesar 40.5\%. Sisanya yakni 59.5\% dipengaruhi oleh variabel di luar penelitian ini.
\end{abstract}

Kata Kunci: Persepsi, Media Sosial, Hoax

Andi Setyawan, 2019. Pengaruh Persepsi dan Penggunaan Media Sosial Terhadap Terpaan Berita Hoax di Kalangan Pelajar SMA Negeri di Pesanggrahan. 


\section{PENDAHULUAN}

Perkembangan sosial media kini semakin masif, keberadaannya ikut mempengaruhi perkembangan kehidupan sosial masyarakat, terutama dalam hal menyajikan berita-berita yang aktual (Nurkinan, 2017). Perkembangan teknologi informasi membawa sebuah perubahan dalam masyarakat. Keberadaan sosial media sangat mempengaruhi pola perilaku masyarakat yang mengakibatkan adanya pergeseran budaya, norma, dan etika. Jumlah penduduk yang besar dengan keragaman ras, suku dan agama, memungkinkan terjadinya perubahan sosial dalam masyarakat. Semua masyarakat dari berbagai kalangan dan usia menggunakan media sosial untuk mendapatkan informasi dan menyebarkan informasi ke publik

Fungsi utama dari media sosial adalah sebagai media untuk berekspresi yang ditandai dengan penyampaian aspirasi berupa informasi, dan menjadi sarana untuk mendapatkan informasi dari luar secara cepat. Berdasarkan fungsi tersebut, jika media sosial dapat digunakan secara bijak maka banyak aspek positif yang bisa didapatkan oleh penggunanya. Namun kenyataannya, media sosial juga dimanfaatkan oleh oknum-oknum yang tidak bertanggung jawab untuk menyebarkan berita-berita yang tidak benar.

Penyebaran berita atau informasi yang berisi konten HOAX tertinggi berasal dari media sosial berupa: Facebook 92, 40 persen; Aplikasi Chatting 62, 62 persen; dan Situs Web 34,40 persen. Kemudian, 88.60 persen berita yang tersebar adalah tentang SARA, dan 41.20 persen berita yang tersebar adalah berita yang bertemakan kesehatan. Setiap harinya 44.30 persen dari 1.116 orang mendapatkan berita hoax, dan 17.20 persen mendapatkan berita hoax lebih dari satu kali dalam satu hari (http://mastel.id/press- releaseinfografis-hasil-survey-mastel-tentangwabah-hoax-nasional/ diakses pada 18 April 2018 Pukul 15.30).

Unsur hoax kurang lebih sama unsur "penipuan", tujuan dari penyebaran hoax tidak selamanya pasti dan bias diduga. Oleh karenanya, hoax dapat dikategorikan sebagai perbuatan yang memiliki implikasi pidana. Karena menyebarkan berita bohong akan mudah mempengaruhi orang lain jika disebarkan secara masif. Hal ini merupakan "rantaian" kebohongan yang bersambung dari individu ke individu lainnya. Hoax bisa berdampak negatif ketika seorang individu mempercayai berita bohong tersebut, dan melanjutkan berita tersebut kepada orang lain.

Terkhusus peneliti tertarik ketika Terpaan berita hoax baru-baru ini menggemparkan media sosial di awal tahun 2019 dengan sebuah berita seorang siswi SMP yang disiksa oleh seniornya. Menurut pihak Polres Pontianak, hal ini disebabkan permasalahan asmara yang tidak adanya hubungan dengan korban, melainkan dengan kakak korban, dan masalah orang tua pelaku yang meminjam uang dan selalu diungkit oleh korban. Padahal uang tersebut telah lama dikembalikan oleh orang tua pelaku. Karena faktor inilah kekerasan terjadi antara korban dan pelaku, hingga akhirnya tersebar di media sosial. Hal ini menimbulkan rasa simpati dan empati warganet, dan pada akhirnya menyebarkan berita ini seluas-luasnya dan membuat snapgram kesedihan serta mentrendingkan tagar \#JusticeForAudrey. Tagar ini sempat menjadi trending nomor 1 di dunia media sosial. Bukan hanya warganet, kalangan pejabat maupun public figure pun ikut memberikan rasa empatinya dengan menyebarkan tagar tersebut (Tribunnews, 2019).

Waktu berlalu dengan tagar yang masih hangat dibicarakan, sejumlah bukti dan dugaan baru pun keluar. Bukti dan 
dugaan tidak adanya kekerasan seksual yang dilakukan oleh pelaku menurut hasil visum pun membuat banyak warganet yang menarik simpati kepada Audrey terlebih setelah melihat akun media sosial facebook yang tidak dibayangkan sebelumnya oleh masyarakat. Hingga muncul tagar baru yang disebarkan oleh warganet yang sudah tidak bersimpati lagi terhadap kasus ini, dengan tagar \#AudreyJugaBersalah.

Ternyata tanggapan warganet sangat positif terhadap informasi hoax tersebut. Hal ini ditunjukkan dengan semakin banyaknya netizen yang merepost berita tersebut, sehingga informasi hoax tersebut cepat tersebar tanpa adanya klarifikasi terlebih dahulu. Dengan demikian konstruksi informasi hoax dan respon netizen memiliki korelasi positif dan signifikan terhadap pemberitaan hoax di media sosial. Artinya kedua variabel tersebut memberikan pengaruh yang cukup signifikan dalam pemberitaan hoax di media online (Slamet, 2018).

Berdasarkan pemaparan diatas maka pertanyaan penelitian dalam penelitian ini adalah apakah terdapat pengaruh antara persepsi dan penggunaan media sosial terhadap terpaan berita hoax di kalangan remaja. Tujuan dari penelitian ini untuk melihat pengaruh mana yang paling besar dalam menghadapi terpaan berita hoax.

\section{MATERI DAN METODE}

Terpaan berita hoax yang dimaksud adalah kegiatan seseorang mendengar, melihat, dan membaca pesan-pesan tentang berita hoax ataupun mempunyai pengalaman dan perhatian terhadap berita tersebut yang dapat terjadi pada tingkat individu maupun kelompok (Albert, 2013). Berita hoax ditunjukkan oleh adanya informasi yang direkayasa untuk menutupi informasi sebenarnya. Hoax bertujuan untuk membuat opini publik, menggiring opini publik, membentuk persepsi juga untuk having fun dengan menargetkan untuk mempengaruhi kecerdasan dan kecermatan pengguna media sosial.

Adapun hal yang menyebabkan berita hoax beredar secara cepat adalah minimnya pengetahuan masyarakat untuk berdemokrasi secara sehat dan tidak terbiasanya masyarakat berpendapat di muka umum. Untuk mencegah penyebaran Hoax dapat dilakukan dengan literasi media. Oleh karena itu, pentingnya literasi media agar pesan dapat diinterpretasikan dengan baik oleh masyarakat, sesuai dengan nilai dan norma yang berlaku. Literasi media akan mengajari khalayak media untuk kritis dalam kemampuan menganalisis pesan media, memahami bahwa media memiliki tujuan komersial, bisnis serta politik sehingga dapat bertanggung jawab dan memberikan respon positif ketika berhadapan dengan media (Rochimah, 2011).

\section{Persepsi}

Persepsi berasal dari bahasa Latin yaitu perceptio, percipio dikategorikan sebagai kegiatan, mengenali,menyusun, dan menafsirkan informasi sensoris untuk mendapatkan gambaran serta pemahaman tentang lingkungan. Persepsi juga merupakan proses seseorang dapat memilih, mengolah, menyimpan, serta menginterpretasikan informasi-informasi yang telah dikumpulkan melalui inderanya (John, 2010). Persepsi diri digambarkan sebagai emosi yang timbul atas pengalaman peristiwa tertentu, serta hubungannya terhadap sesuatu. Robbin menjelaskan indikator persepsi terdiri dari 2: yang pertama adalah penerimaan indera untuk menangkap rangsangan dari luar, yang kedua evaluasi terhadap penerimaan tersebut (Stephen, 2003).

\section{Penggunaan Media Sosial}

Penggunaan media sosial adalah penelusuran penggunaan layanan pencarian, pengambilan dan pembagian 
media (foto, berita, dan video) pada smartphone ataupun komputer yang terdiri dari beberapa dimensi yang dikaji dalam bidang ilmu sosial dan behavioral (Westermann, 2010).

\section{Hipotesis Penelitian}

1. $\mathrm{H}^{01:}$ Ada pengaruh yang signifikan dari persepsi terhadap terpaan berita hoax.

2. $\mathrm{H}^{02}$ : Ada pengaruh yang signifikan dari penggunaan media sosial terhadap terpaan berita hoax.

\section{Metode Penelitian Populasi \& Sampel}

Populasi dalam penelitian ini terdiri atas siswa dan siswi SMA Negeri yang ada di Kecamatan Pesanggrahan. Pengambilan sampel yang digunakan dengan menggunakan teknik klaster.

\section{Variabel Penelitian}

1. Variabel terikat : terpaan berita hoax.

2. Variabel bebas : Persepsi \& Penggunaan Media Sosial

\section{Definisi Operasional Variabel}

1. Terpaan berita Hoax adalah kegiatan orang ketika mendengar, melihat, serta membaca pesan tentang berita hoax ataupun memiliki pengalaman dan perhatian terhadap berita tersebut yang dapat terjadi pada kelompok maupun individu (Albert, 2013).

2. Persepsi dapat digambarkan sebagai proses seseorang dapat memilih, mengelola, menyimpan, serta menginterpretasikan informasiinformasi yang telah dikumpulkan melalui inderanya (John, 2010).
3. Penggunaan media sosial adalah penelusuran penggunaan layanan pencarian, pengambilan dan pembagian media (foto, berita, dan video) pada smartphone ataupun komputer yang terdiri dari beberapa dimensi yang dikaji dalam bidang ilmu sosial dan behavioral (Westermann, 2010)

\section{Teknik Pengumpulan Data}

Dalam penelitian ini, teknik pengumpulan data menggunakan skala sebagai alat pengumpul data.

Tabel

\section{Skor Skala Likert}

\begin{tabular}{|l|c|}
\hline Skala & Favorable \\
\hline Sangat Setuju (SS) & 4 \\
Setuju (S) & 3 \\
Tidak Setuju (TS) & 2 \\
Sangat Tidak Setuju & 1 \\
(STS) & \\
\hline
\end{tabular}

Tabel

\section{Blue Print Alkat Ukur Terpaan Berita Hoax}

\begin{tabular}{|l|l|l|}
\hline No & Aspek & Indikator \\
\hline 1 & $\begin{array}{l}\text { Mende } \\
\text { ngar }\end{array}$ & $\begin{array}{l}\text { Mendengar berita } \\
\text { tentang kasus Audrey } \\
\text { secara umum }\end{array}$ \\
\hline 2 & $\begin{array}{l}\text { Meliha } \\
\mathrm{t}\end{array}$ & $\begin{array}{l}\text { melihat secara } \\
\text { langsung berita } \\
\text { tentang Audrey }\end{array}$ \\
\hline 3 & $\begin{array}{l}\text { Memb } \\
\text { aca }\end{array}$ & $\begin{array}{l}\text { a. Membaca berita } \\
\text { tentang audrey } \\
\text { b. Percaya bahwa } \\
\text { berita Audrey } \\
\text { hoax }\end{array}$ \\
\hline
\end{tabular}




\begin{tabular}{|l|l|l|}
\hline 4 & $\begin{array}{l}\text { Pengal } \\
\text { aman }\end{array}$ & $\begin{array}{l}\text { a. Merasakan bahwa } \\
\text { Audrey memang } \\
\text { bersalah } \\
\end{array}$ \\
& $\begin{array}{l}\text { b. Merasakan bahwa } \\
\text { individu pernah } \\
\text { mengalami seperti } \\
\text { audrey }\end{array}$ \\
\hline
\end{tabular}

Tabel

\section{Blue Print Alat Ukur Persepsi}

\begin{tabular}{|c|c|c|}
\hline No & Aspek & Indikator \\
\hline 1 & $\begin{array}{l}\text { Peneri } \\
\text { maan }\end{array}$ & $\begin{array}{l}\text { a. Memperoleh } \\
\text { berita Audrey dari } \\
\text { Instagram } \\
\text { b. Mendengar berita } \\
\text { Audrey dari } \\
\text { lingkungan } \\
\text { terdekat (sekolah) }\end{array}$ \\
\hline 2 & $\begin{array}{l}\text { Evalua } \\
\text { si }\end{array}$ & $\begin{array}{l}\text { a. Langsung percaya } \\
\text { berita hoax } \\
\text { b. Memikirkan dan } \\
\text { mempertimbangk } \\
\text { an dahulu terkait } \\
\text { kebenaran } \\
\text { c. Mencari Tahu } \\
\text { kebenaran } \\
\text { mengenai berita } \\
\text { hoax }\end{array}$ \\
\hline
\end{tabular}

Tabel

Blue Print Alkat Ukur Penggunaan Media Sosial Instagram

\begin{tabular}{|l|l|l|}
\hline No & Aspek & Indikator \\
\hline 1 & Jaring & $\begin{array}{l}\text { a. Menggunakan } \\
\text { an } \\
\text { handphone untuk } \\
\text { mendapatkan } \\
\text { informasi } \\
\text { b. Mendapatkan } \\
\text { informasi dari } \\
\text { akun Instagram } \\
\text { teman }\end{array}$ \\
\hline 2 & $\begin{array}{l}\text { Infor } \\
\text { masi }\end{array}$ & $\begin{array}{l}\text { a. Mendapatkan } \\
\text { informasi dari } \\
\text { poster yang viral }\end{array}$ \\
\hline
\end{tabular}

\begin{tabular}{|c|c|c|}
\hline & & $\begin{array}{l}\text { b. Memperoleh } \\
\text { informasi dari } \\
\text { tagar } \\
\text { \#justiceforaudrey }\end{array}$ \\
\hline 3 & Arsip & $\begin{array}{l}\text { Dapat melihat } \\
\text { berita tersebut } \\
\text { menerus di } \\
\text { instagram }\end{array}$ \\
\hline 4 & $\begin{array}{l}\text { intera } \\
\text { ktif }\end{array}$ & $\begin{array}{l}\text { a. Menandatangani } \\
\text { petisi Justice for } \\
\text { Audrey } \\
\text { b.Memberikan } \\
\text { komentar } \\
\text { terhadap berita } \\
\text { Audrey } \\
\text { c. Memposting berita } \\
\text { Audrey }\end{array}$ \\
\hline
\end{tabular}

\section{Analisa Data}

Sebelum melakukan analisis data, digunakan Confirmatory Factor Analysis (CFA) untuk melihat validitas konstruk setiap item serta menguji struktur faktor yang diturunkan secara teoritis. Pada penelitian ini digunakan multiple regression analysis di mana terdapat lebih dari satu independent variable agar terlihat pengaruh kepada dependent variable. Penelitian ini menggunakan rumus persamaan regresi:

$$
\mathrm{Y}=\mathrm{a}+\mathrm{b} 1 \mathrm{X} 1+\mathrm{b} 2 \mathrm{X} 2+\ldots+\mathrm{e}
$$

Keterangan:

$\mathrm{Y}=\mathrm{Terpaan}$ berita hoax

$\mathrm{a}=$ Konstan

$\mathrm{b}=$ Koefisien regresi untuk masing-masing $\mathrm{X}$

$\mathrm{X} 1=$ Persepsi

$\mathrm{X} 2$ = Penggunaan media sosial

$\mathrm{e}=$ Residual

Melalui regresi berganda ini akan diperoleh nilai koefisien determinasi yaitu $\mathrm{R}^{2}$, $\mathrm{R}^{2}$ menunjukkan variasi atau 
perubahan dependent variable (Y) disebabkan independent variable (X) atau dimanfaatkan untuk mendapatkan besarnya pengaruh independent variable (X) terhadap dependent variable (Y) atau merupakan perkiraan proporsi varians dari perilaku hedonis yang dijelaskan oleh seluruh independent variable. Untuk mendapatkan nilai $\mathrm{R}^{2}$, digunakan rumus sebagai berikut:

$$
R^{2}=\frac{S S_{r e g}}{S S_{y}}
$$

Keterangan:

$\mathrm{R}^{2}=$ Koefisien determinasi

SSreg = Sum of Square Regression

SSy = Sum of Square $\mathrm{Y}$

Selanjutnya $\mathrm{R}^{2}$ dapat diuji signifikansinya seperti uji signifikansi pada F-test. Selain itu juga, uji signifikansi dilakukan untuk melihat apakah terdapat pengaruh antara IV terhadap DV signifikan atau tidak. Pembagi disini adalah $\mathrm{R}^{2}$ itu sendiri dengan df-nya (dilambangkan ' $\mathrm{k}$ '), yaitu sejumlah IV yang dianalisis sedangkan penyebutnya $\left(1-\mathrm{R}^{2}\right)$ dibagi dengan df-nya (N-k-1) dimana $\mathrm{N}$ adalah total sampel. Untuk df dari pembagi sebagai numerator sedangkan df penyebut sebagai denumerator. Jika dirumuskan, maka:

$$
F=\frac{R^{2} / k}{\left(1-R^{2}\right) /(N-k-1)}
$$

Keterangan:

$\mathrm{R}^{2}=$ Proposi varians

$\mathrm{k}$ = Banyaknya independent variable

$\mathrm{N}=$ Ukuran sampel
Kemudian selanjutnya dilakukan uji koefisiensi regresi dari tiap-tiap IV yang dianalisis. Uji tersebut digunakan untuk melihat apakah pengaruh yang diberikan IV signifikan terhadap DV secara sendirisendiri atau parsial. Pengujian ini dilakukan untuk mengetahui apakah sebuah IV benar-benar memberikan kontribusi terhadap DV. Sebelum di dapat nilai $\mathrm{t}$ dari tiap IV, harus didapat dahulu nilai standard error estimate dari b (koefisien regresi) yang didapatkan melalui akar MSres dibagi dengan SSx. Setelah didapat nilai $\mathrm{Sb}$ barulah bisa dilakukan uji t, yaitu hasil bagi dari $b$ (koefisien regresi) dengan $\mathrm{Sb}$ itu sendiri. Dapat dirumuskan:

$$
t_{i}=\frac{b_{i}}{S_{b i}}
$$

Keterangan:

bi $=$ Koefisien regresi ke-i

Sbi $=$ Standart Error Estimate dari bi

HASIL DAN PEMBAHASAN

Gambaran Subjek Penelitian

Tabel

\section{Gambaran Umum Subjek Penelitian}

\begin{tabular}{|l|l|l|}
\hline Deskripsi & N & $\%$ \\
\hline Asal Sekolah & & \\
SMAN 63 & 43 & $40,56 \%$ \\
SMAN 86 & 21 & $19,81 \%$ \\
SMAN 90 & 22 & $20,75 \%$ \\
SMAN 108 & 20 & $18,86 \%$ \\
Jenis Kelamin & & \\
Laki-Laki & 42 & $39,62 \%$ \\
Perempuan & 64 & $60,37 \%$ \\
Kelas & & \\
11 & 34 & $32,07 \%$
\end{tabular}




\begin{tabular}{|l|l|l|}
12 & 72 & $67,92 \%$ \\
\hline Jumlah & 106 & \\
\hline
\end{tabular}

Sumber: Hasil Penelitian, 2019

\section{Analisa Regresi}

Tabel

Model Summary Analisis Regresi

\begin{tabular}{lllll}
$\begin{array}{l}\text { mod } \\
\text { el }\end{array}$ & $\mathrm{R}$ & $\begin{array}{l}\text { Rsqua } \\
\text { re }\end{array}$ & $\begin{array}{l}\text { Adjust } \\
\text { ed R } \\
\text { Square }\end{array}$ & $\begin{array}{l}\text { Std. } \\
\text { Error of } \\
\text { the } \\
\text { Estimat } \\
\text { ed }\end{array}$ \\
\hline 1 & .63 & .405 & .393 & 7.78993 \\
& $6 \mathrm{a}$ & & &
\end{tabular}

Sumber: Hasil Penelitian, 2019

a.Predictors: (Constant), Penggunaan media social, Persepsi

terlihat bahwa nilai $\mathrm{R}$ Square dalam penelitian ini sebesar 0.405 atau $40.5 \%$. Hal ini bermakna bahwa pengaruh variabel persepsi dan penggunaan media sosial terhadap terpaan berita hoax sebesar $40.5 \%$. Sisanya yakni $59.5 \%$ dipengaruhi oleh variabel di luar penelitian ini.

Tabel

Koefisien Regresi

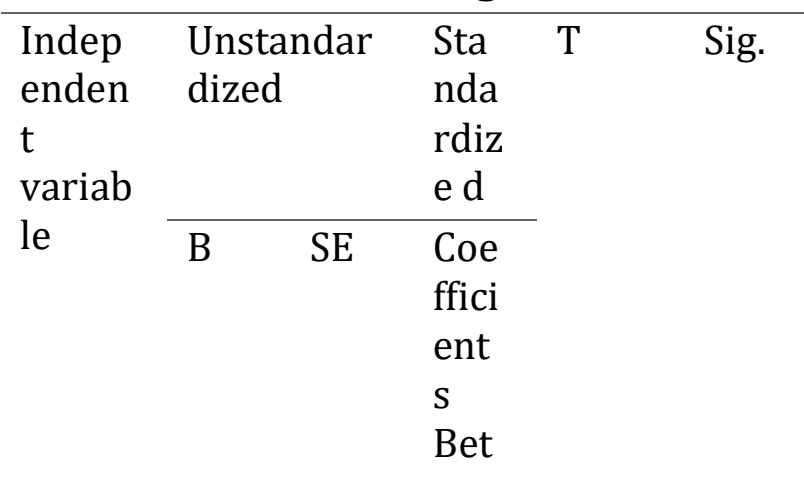

a

\begin{tabular}{llllll}
\hline Const & 14. & 4.5 & & 3.09 & .00 \\
ant) & 087 & 59 & & 0 & 3 \\
\cline { 2 - 6 } Perse & .18 & .08 & .18 & 2.15 & .03 \\
psi & 2 & 4 & 2 & 8 & $3^{*}$ \\
Pengg & .53 & .08 & .53 & 6.37 & .00 \\
unaan & 7 & 4 & 7 & 3 & $0^{*}$ \\
\hline
\end{tabular}

Media

Sosial

Sumber: Hasil Penelitian, 2019

Variabel Persepsi diperoleh nilai koefisien regresi sebesar 0.182 dengan nilai signifikansi 0.033 . Hal ini bermakna bahwa H1 yang menyatakan "ada pengaruh yang signifikan dari terhadap terpaan berita hoax" diterima. Artinya ada pengaruh yang signifikan dari persepsi terhadap terpaan berita hoax. Koefisien bertanda positif artinya semakin sering pelajar mempersepsikan sesuatu maka semakin tinggi pula terpaan berita hoax yang terjadi dikalangan pelajar SMA Negeri di Pesanggrahan.

Variabel Penggunaan Media Sosial Diperoleh nilai koefisien regresi sebesar 0.537 dengan nilai signifikansi 0.000 . Hal ini bermakna $\mathrm{H} 2$ yang menyatakan "ada pengaruh yang signifikan dari penggunaan media sosial terhadap perilaku hedonis" diterima. Sehingga dapat diartikan bahwa penggunaan media sosial berpengaruh secara signifikan terhadap terpaan berita hoax yang terjadi dikalangan pelajar SMA Negeri di Pesanggrahan.

\section{KESIMPULAN DAN IMPLIKASI}

\section{Kesimpulan}

Berdasarkan hasil analisis data yang telah dilakukan, maka kesimpulan yang dapat didapat dari penelitian ini adalah, Dari hasil penelitian didapatkan pengaruh signifikan antara persepsi terhadap terpaan berita hoax dengan koefisien regresi 0,182 lebih besar $\mathrm{dr}$ 0,05 , dan terdapat pengaruh yang signifikan antara penggunaan media sosial terhadap terpaan berita hoax dengan koefisien regresi 0,537 lebih besar dari 0,05. Selanjutnya didapatkan hasil $\mathrm{R}$ Square dalam penelitian ini sebesar 0.405 atau $40.5 \%$. Hal ini bermakna bahwa pengaruh variabel persepsi dan penggunaan media sosial terhadap terpaan berita hoax sebesar 
40.5\%. Sisanya yakni 59.5\% dipengaruhi oleh variabel di luar penelitian ini.

\section{Saran}

Kami sebagai peneliti memberikan saran agar hasil penelitian ini dapat menjadi acuan bagi masyarakat khususnya pelajar untuk lebih objektif terhadap suatu persoalan yang ada di media sosial sehingga tidak munculnya berita hoax kepada masyarakat banyak. Untuk penelitian pengembangan sangat disarankan untuk menyempurnakan dan mencari faktor yang mempengaruhi berita hoax diluar 40,5\% misalnya seperti kurangnya minat baca seseorang, ataupun karena kurangnya pengajaran akan berita hoax melalui pendidikan formal agar terpaan berita hoax dapat diantisipasi oleh masyarakat.

\section{DAFTAR PUSTAKA}

Albert, G. (2013). Pengaruh Terpaan Berita Hoax dan Persepsi Masyarakat Tentang Kualitas Pemberitaan Televisi Berita Terhadap Intensitas Menonton Televisi Berita. Universitas Diponegoro.

John, W. (2010). Organizational Behavior: Securing Competitive Advantage. New York: Routledge.

Nurkinan. (2017). Dampak Media Online Terhadap Perkembangan Media Konvensional. Karawang. Karawang: UNISKA.

Rochimah. (2011). Gerakan Literasi Media: Melindungi Anak-Anak dari Gempuran Pengaruh Media. Yogyakarta: Rumah Sinema.

Slamet, Y. (2018). Pemberitaan Hoax di Media Online Ditinjau dari Konstruksi Berita dan Respon Netizen. Universitas Pendidikan Negeri Yogyakarta.

Stephen, R. (2003). Perilaku Organisasi. Jakarta: Index.

Tribunnews. (2019). Bukan Hanya Saling
Sindir Soal Mantan Pacar, Pelaku Perundungan Audrey Juga Tersinggung Soal Utang. Retrieved from

https://style.tribunnews.com/201 9/04/10/bukan-hanya-salingsindir-soal- mantan-pacar-pelakuperundungan-audrey-jugatersinggung-soal-utang

Westermann. (2010). The Effects of Social Media On College Students. Retrieved from USA 